\title{
Growth and Ethylene Production in Eucalyptus Clones Sensitive to Shoot Blight, Submitted to Hypoxia and High Levels of Manganese
}

\author{
Fellip Januário Pinheiro Lacerda \\ Ivo Ribeiro da Silva \& Fernanda Schultais \\ Viçosa Federal University, Brasil.
}

\begin{abstract}
Sarah Vieira Novais
Escola Superior de Agricultura Luiz de Queiroz (ESALQ),

São Paulo University, Brazil.

Fernando Palha Leite

Celulose Nipo Brasileira S/A, Belo Oriente, Brazil.

Roberto Ferreira Novais (Corresponding author)

Viçosa Federal University, Campus Rio Paranaíba, Brasil.

E-mail:rfnovais@ufv.br
\end{abstract}

Received: November 28, 2017

Accepted: December 12, 2017

doi:10.5296/jas.v6i1.12472

URL: https://doi.org/10.5296/jas.v6i1.12472

\begin{abstract}
Eucalyptus shoot blight in the Rio Doce Valley (ESBVRD) is a physiological anomaly that has been related to hypoxic environment and Mn excess. This study had the objective of understanding the mechanisms involved in the differential tolerance of eucalyptus clones to ESBVRD. Two experiments were carried out: (I) two clones, a sensitive and a ESBVRD tolerant, two $\mathrm{O}_{2}$ concentrations (normal and hypoxic) and five concentrations of $\mathrm{Mn}(0,5$, to $90 \mathrm{mg} \mathrm{L}^{-1}$ ); (II) same two eucalyptus clones, two $\mathrm{O}_{2}$ concentrations (normal and mild hypoxic) and two Mn concentrations (30 and $300 \mathrm{mg} \mathrm{L}^{-1}$ ). The hypoxic condition reduced the plant dry
\end{abstract}


weight and increased the production of ethylene in the two clones, both more strikingly in the sensitive clone. The $\mathrm{O}_{2}$ deficiency was the first factor predisposing the clones to ESBVRD, in contrast to Mn excess, that appeared to act over a longer period for the expression of the symptoms.

Keywords: flooding, forestry nutrition, dieback of the Rio Doce Valley, ESBVRD.

\section{Introduction}

In the lowland regions of the Rio Doce Valley the occurrence of eucalyptus dieback (ESBVRD) has been observed for decades (Nascimento et al., 2006) and causes significant losses in productivity for the plantation. Although the symptoms are principally expressed in the apical region, they are visually different from those of the dieback caused by B deficiency and/or Ca observed in eucalyptus plantations in the region of Cerrado (Novais et al., 1990; Gonçalves et al., 2016).

In the initial stages brownish necroses are observed at the insertion of the secondary stems and petioles, especially in the region below the emission of new branches. The leaves become coriaceous and wrinkled and the lesions evolve rapidly leading to the death of the apical part of the branch, compromising plant growth. In the more severe case complete defoliation occurs, culminating in the death of the apex of the plant (Leite et al., 2014). According to these authors the intensity of visual symptoms is related to the age of the plants, as they are normally observed until the third or fourth year after planting. This is probably due to the increase in leaf area index when the plants become older (3-4 years), accommodating the higher transpirational demands of the plants. In this way the hypoxic condition can be minimized by the increase in the flux of water in the soil-plant-atmosphere system, reducing plant stress. In the lowland region of the Rio Doce Valley, ESBVRD has appeared sporadically and occurred with a higher intensity in years with very wet summers, such as 2002 and 2007. The visual symptoms reach their height between April and May (end of the wet season), but there is a recovery in growth at the end of the dry period (August-September) (Leite et al., 2014).

Under stress, such as frost, flooding and mechanical stress, the synthesis of ethylene by plants is increased (Taiz e Zeiger, 2006; Urano et al., 2017; Telewski, 2016; Zhang et al., 2016). That is because the expression of the gene that regulates ethylene synthesis is increased in hypoxic conditions (Alpuerto et al., 2016; Bailey-Serres and Voesenek, 2008; Dong et al., 2016; Keunen et al., 2016; Peng et al., 2005). Clemens and Pearson (1977), studying Eucalyptus robusta, observed that in roots and branches the rate of ethylene production was doubled after six days of hypoxia, but without the production of this compound in the leaves. Andrade et al. (2015) observed the excessive accumulation of ethylene in trees typical of a tropical forest (Parkia gigantocarpa) caused by the excess of $\mathrm{Fe}^{2+}$ and $\mathrm{Mn}^{2+}$ in flooded areas, causing a reduction in growth of even root death. Even in plants recognized as being tolerant to flood ethylene production was high in the secondary roots, allowing an increase in the absorption of oxygen and nutrients.

The hypoxic environment (reducing) caused the solubilization of Fe and Mn oxides and 
hydroxides, making these elements available in toxic levels (Huang et al., 2015; Khabaz-Saberi et al., 2006). Thus, it is believed that hypoxia associated with elevated levels of $\mathrm{Mn}$ in the soil are the principal factors for the expression of the visual symptoms of ESBVRD.

A large difference in the level of leaf Mn were observed between the sensitive (3070 mg kg ${ }^{-1}$ ) and the tolerant $\left(734 \mathrm{mg} \mathrm{kg}^{-1}\right)$ clone, indicating the involvement of this micronutrient in the appearance of ESBVRD (Leite et al., 2014). However, it is not known whether these levels of $\mathrm{Mn}$ in the sensitive clone are sufficiently elevated to cause damage to plant metabolism and growth, or the excess of $\mathrm{Mn}$ is the cause or only an effect of the inefficient mechanisms of the ESBVRD sensitive clones. Indeed, a lower tolerance to Mn could result from a lower restriction on its absorption and/or its translocation to the aerial part of the plant or its efficient inactivation inside the plant tissues. Lidon and Teixeira (2000) concluded that, depending on the species, the excess Mn could accumulate in vacuoles, the cell wall and the thylakoids, increasing tolerance to the high levels of $\mathrm{Mn}$ available in some species. It is known that plants subjected to high light intensity or elevated temperature are more likely to be predisposed to Mn toxicity (El-Jaoual and Cox, 1998). These factors are of great importance in lowland regions subjected to flooding, where ESBVRD occurs at a high frequency. These conditions of high temperature are observed practically throughout the whole year (Leite et al., 2014).

Muhammad et al. (2016) found a differential reduction in the chlorophyll content and photosynthetic attributes (rate of photosynthesis, transpiration and stomatal conductance), varying according to the genotype (variety), after the addition of toxic doses of $\mathrm{Mn}$. The excess of this micronutrient is extremely damaging to photosynthesis, leading to a reduction in root growth and plant height. However, the most tolerant genotypes tend to have a lower level of $\mathrm{Mn}$ in their tissues, principally in the plasma membrane and the cell wall, resulting in higher plant biomass. (Xue et al., 2015) confirmed that tolerance to Mn varied according to chloroplast resistance. The accumulation of $\mathrm{Mn}$ in the chloroplast structure leads to the excess production of laminar granules, rupturing of the membrane and the entire structure of the chloroplast, causing one of the most common symptoms of Mn toxicity, dark spots on the leaves.

In general, Mn toxicity is characterized by necrotic spot on the leaves, petioles and stems, starting with the older leaves and spreading with time to the younger leaves. In some species, the symptoms of toxicity can start as leaf chlorosis that may cause the leaf to wrinkle and even tipping of the stem and petiole (Asati et al., 2016).

A common symptom of Mn toxicity is dark spots on the older leaves with chlorosis at the edges and he youngest become wilted with interneval chlorosis and along the edges (El-Jaoual and Cox, 1998). Wu (1994) suggested that brown spots are common in leaves, petioles and stems and are useful in the diagnosis of Mn toxicity in soybean. In apple trees, the symptoms of $\mathrm{O}_{2}$ deficiency are characterized by the cracking of the bark of the trunk and secondary branches (Ernani, 2012), similar to the symptoms of ESBVRD. Winterhalder (1963), studying native Australian species, like Eucalyptus gummifera, verified that Mn 
toxicity was indicated by the presence of small chlorotic leaves, with wrinkling in some cases and death of the apical tissue in extreme cases.

In view of the above, the objective of this work was to evaluate the tolerance of saplings eucalyptus clones, previously identified as having differential sensitivity to Rio Doce Valley dieback (ESBVRD), under hypoxic conditions and the excess of Mn.

\section{Material and Methods}

The eucalyptus seedlings utilized in the experiments were produced by min-cuttings from the nursery CENIBRA (Celulose Nipo-Brasileira S.A.), Belo Oriente - MG. The clones used 1213 (sensitive) and 2719 (tolerant to ESBVRD), were hybrids between the species Eucalyptus urophylla $x$ E. grandis (Eucalyptus urograndis). The option to use these clones was due to the observations that in the field 1213 is more sensitive to dieback (Leite et al., 2014).

At 25 to 30 days old, the seedlings were transferred to the greenhouse. After five days of acclimatization in the original tubes, they were removed from the substrate, washed with deionized water and transferred to $10 \mathrm{~L}$ trays containing half strength Clark's nutrient solution without $\mathrm{Mn}$. The solutions were constantly aerated and the $\mathrm{pH}$ maintained at 5.0 $\left(0.01 \mathrm{~mol} \mathrm{~L}^{-1} \mathrm{HCl}\right.$ or $\left.\mathrm{NaOH}\right)$. The plants remained in the trays for 5 days in the greenhouse and were then transferred to a growth chamber. The clones were maintained under controlled illumination $\left(600 \mu \mathrm{mol} \mathrm{m} \mathrm{m}^{-2} \mathrm{~s}^{-1}\right.$ ), with a 12 hour light 12 hour dark photoperiod, the temperature controlled to $30 \pm 2{ }^{\circ} \mathrm{C}$ and a relative humidity of approximately $70 \%$.

In Experiment I, the eucalyptus seedlings (clones 1213 and 2719) already acclimatized and in the growth chamber, were arrange individually in $3.4 \mathrm{~L}$ plastic recipients containing full strength Clark's nutrient solution without Mn. The experimental unit was consisted one plant per recipient.

The treatments were arranged in a factorial scheme of $2 \times 2 \times 5$, two clones (sensitive 1213 and tolerant 2719 to ESBVRD; two concentration of $\mathrm{O}_{2}$ in the solution (normal $8 \mathrm{mg} \mathrm{L}^{-1}$ and severe hypoxic $1 \mathrm{mg} \mathrm{L}^{-1}$ of $\mathrm{O}_{2}$ ), and five concentrations of $\mathrm{Mn}$ (as $\mathrm{MnCl}_{2} \cdot 4 \mathrm{H}_{2} \mathrm{O}, 0,5,10,30$ and $90 \mathrm{mg} \mathrm{L}^{-1}$ ). The treatments were arrange in a randomized block with four repetitions.

The nutrient solution was changed weekly and the $\mathrm{pH}$ adjusted daily to 5.0. The plants were grown under the defined experimental conditions for 25 days. To avoid darkening and to stimulate root growth $100 \mu \mathrm{mol} \mathrm{L}{ }^{-1}$ of $\mathrm{Al}$ was added (Silva et al., 2004). The dissolved $\mathrm{O}_{2}$ in each unit was measure with an oxymeter four time a day. In the hypoxic treatments, the low concentration of $\mathrm{O}_{2}$ was maintained by the continuous injection of $\mathrm{N}_{2}$ (Air Products) into the nutrient solution.

After 25 days in the growth chamber, each plant was divided into mature leaves, young leaves, stem and roots, washed three times in deionized water and oven dried at $72{ }^{\circ} \mathrm{C}$. The plant samples were then ground using a Willey mill and submitted to digestion in a nitric-perchloric acid mixture (4:1 v/v) according to the method of Malavolta et al. (1989). The digests were used to determine the level of Mn by atomic absorption spectroscopy. 


\section{Macrothink}

Journal of Agricultural Studies

ISSN 2166-0379

2018, Vol. 6, No. 1

In Experiment II, the same experimental conditions were used with a factorial scheme of $2 \mathrm{x}$ $2 \times 2$, two eucalyptus clones; two concentrations of $\mathrm{O}_{2}$ (normal $8 \mathrm{mg} \mathrm{L}^{-1}$ and mild hypoxic 6 $\left.\mathrm{mg} \mathrm{L}^{-1}\right)$, two concentrations of $\mathrm{Mn}\left(30\right.$ and $300 \mathrm{mg} \mathrm{L}^{-1}$, defined by the results of Experiment I). During the experimental period the solution was constantly aerated, the $\mathrm{pH}$ adjusted to 5.0 daily and the solution changed weekly as described for Experiment I. The assay was conducted with eight replicates in a randomized block design.

The length of the root system was measured at $0,2,5,10,15,18$ and 27 days and the aerial part of the plant at 0 and 27 days. At the end of the experiment, each experimental unit was placed inside a glass bell chamber to isolate it from the external atmosphere. Each plant remained in the chamber for $20 \mathrm{~min}$, the internal air being homogenized mini-fan. After this period, samples were taken, four repetitions per plant, of the internal atmosphere to determine the concentration of ethylene using a gas chromatograph equipped with a Porapak Q column and a flame ionization detector.

Again, at the end of the experiment the plants were divided into mature leaves, young leaves, stem and roots and oven dried at $72{ }^{\circ} \mathrm{C}$. After drying, the samples were ground using a Willey mill, submitted to digestion with nitric-perchloric acid (4:1 v/v, Malavolta et al., 1989) and the concentration of Mn determined by atomic absorption spectroscopy.

The results were submitted to an analysis of variance. Subsequently, the degrees of freedom of treatments were defined and using regression analysis, in Experiment $\mathrm{I}$, the effect of $\mathrm{Mn}$ concentrations on the production of dry vegetable matter, the concentration of $\mathrm{Mn}$ on the growth of the aerial part of the plant in the two clones was investigated. Similarly, in Experiment II, the effect of hypoxia and the concentration of Mn on daily root growth in both clones was investigated and using a test of means (Tukey a $5 \%$ ), the effect of $\mathrm{Mn}$ on the growth of the aerial part of the plant, its height, diameter, concentration of ethylene and root growth. To investigate the effect of the clones the model identity test was applied comparing the regression analyses. The data was analyzed using the statistical package SAEG version 9.1 and the software Sigmaplot to produce the graphs.

\section{Result and Discussion}

\section{Experiment I}

\subsection{Analyses of the Dry Matter from the Plant Components}

In general, both the clones presented a reduced production of dry matter under hypoxia (Figures 1 e 2), certainly, the most important factor is the reduced offer of energy for plant growth under this condition. The plants have reduced metabolism and absorb and transport of nutrients to the aerial part (George et al., 2012), reductions also occur in the transport of water, hormones and other solutes via mass flow (Wang et al., 2016). 


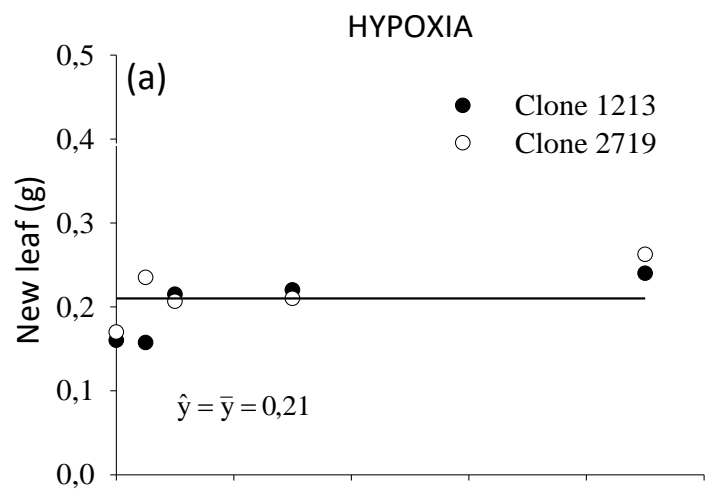

NORMAL

(b)
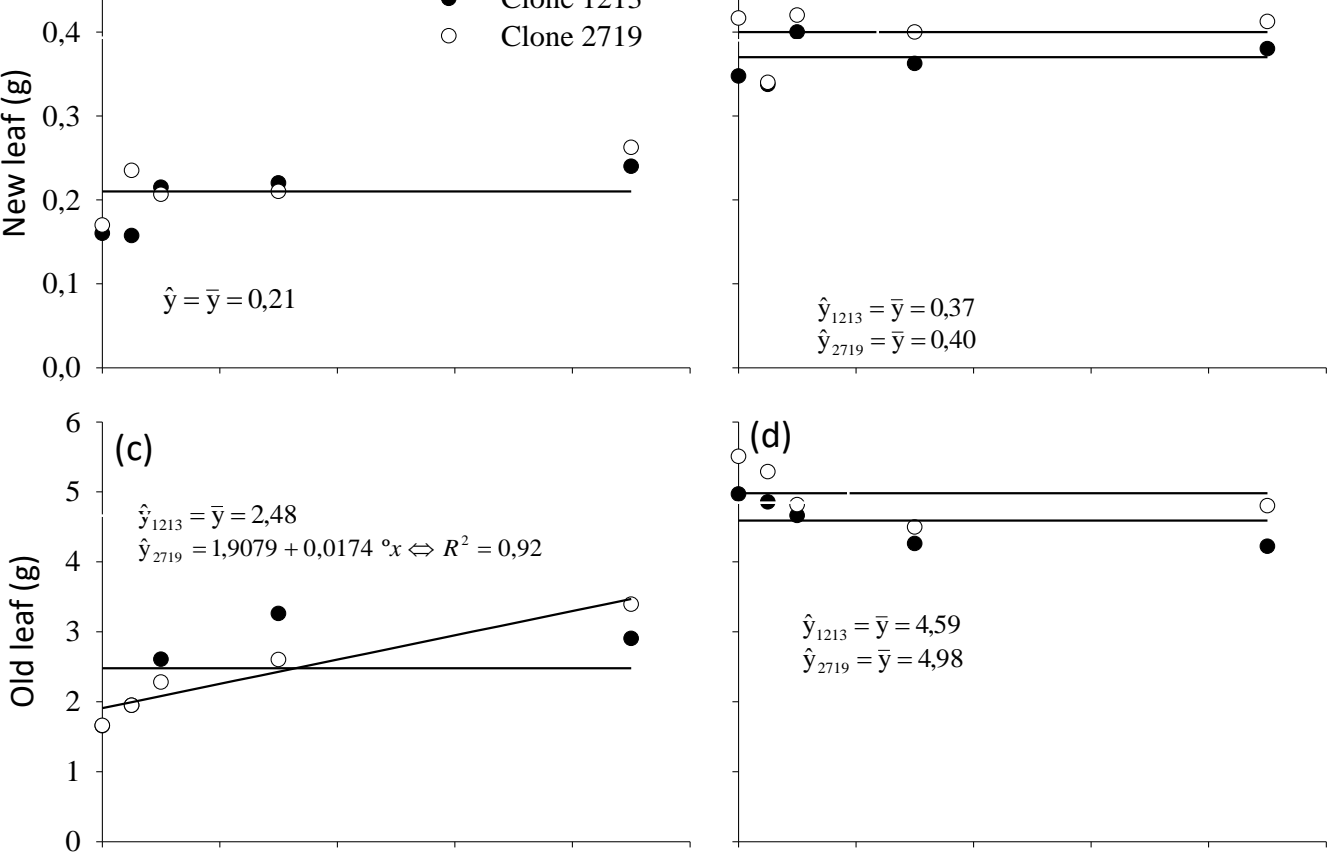

$\hat{\mathrm{y}}_{1213}=\overline{\mathrm{y}}=4,59$

$\hat{\mathrm{y}}_{2719}=\overline{\mathrm{y}}=4,98$
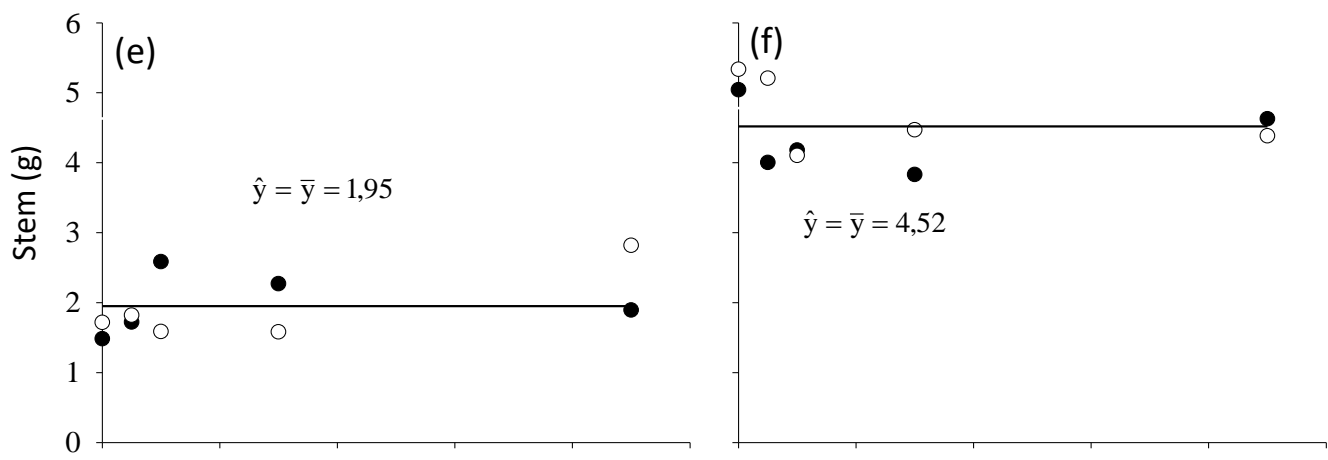

Figl

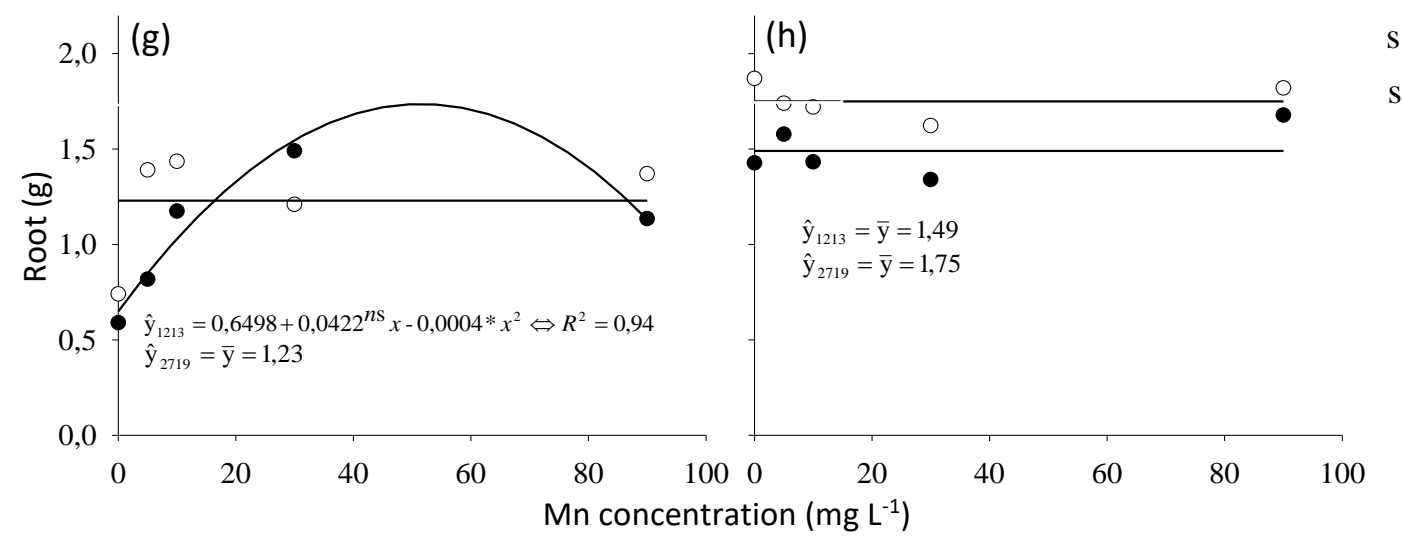

Figure 1. Dry matter yield of new leaf $(\mathrm{a}, \mathrm{b})$ and old $(\mathrm{c}, \mathrm{d})$, stem $(\mathrm{e}, \mathrm{f})$ and root $(\mathrm{g}, \mathrm{h})$ in eucalyptus seedlings (clones 1213®- sensitive- and 2719 To the ESBVRD) influenced by concentrations of Mn and O2 (Hypoxia and Normal) at 25 days. 


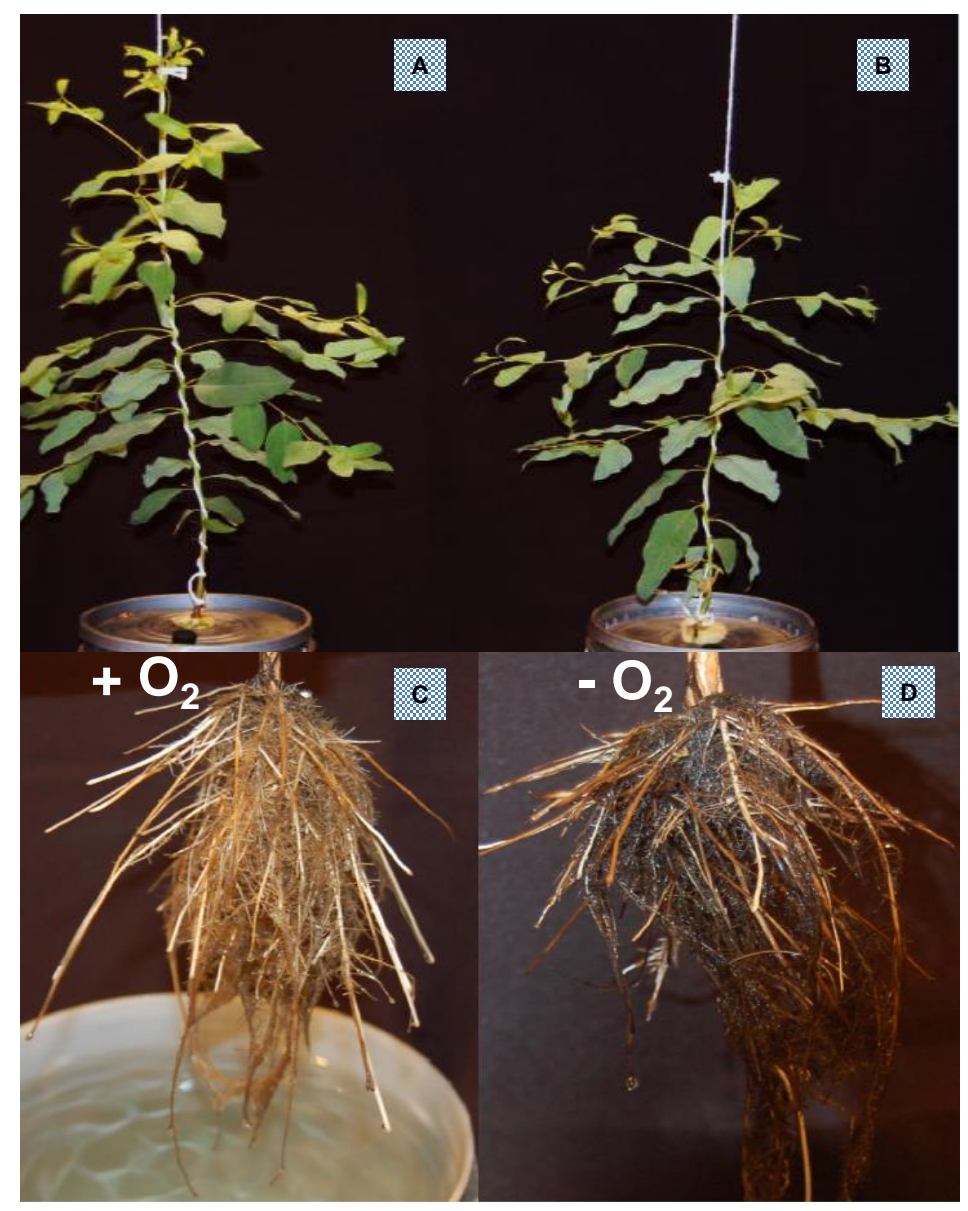

Figure 2. Detail of the aerial part and root system of the sensitive clone (1213®) to SPEVRD submitted to the normal oxygenation condition (+ O2) (A and C) and severe hypoxia (- O2) (B and D).

\section{Level of Mn}

Despite the absence of visual symptoms of deficiency, Mn leaf levels as low as $59 \mathrm{mg} \mathrm{kg}^{-1}$ were observed in young leaves when Mn was not supplied in the nutrient solution (Figure 3). This level of Mn was probably the residue from the initial production phase of the seedlings. Although there was a difference in the absorption of Mn by the clones, the level of Mn considered deficient was similar varying between 10 and $20 \mathrm{mg} \mathrm{kg}^{-1}$, as observed by Shao et al. (2016) in fully expanded leaves and independent of the species, variety and environment (Broadley et al., 2012). On the other hand, levels higher than $8000 \mathrm{mg} \mathrm{kg}^{-1}$ were observed in mature leaves under hypoxia and the higher concentrations of Mn (Figure 3c), for both clones as well as the sensitive clone under normal oxygen levels (Figure 3d). These levels are well above those considered critical for eucalyptus leaves about $400-500 \mathrm{mg} \mathrm{kg}^{-1}$ of $\mathrm{Mn}$ (Gonçalves et al., 1996). Differences in leaf Mn levels were observed between the clones under normal oxygenation, with the sensitive clone showing higher levels (Figure $3 \mathrm{~b}$ e $3 \mathrm{~d}$ ). Under hypoxia, it was evident that there were higher levels of Mn in the roots (Figure $3 \mathrm{~g}$ ) and the stem (Figure 3e) of the tolerant clone. Thus, lower leaf levels of Mn were expected in this clone, probably due to the lower translocation of this micronutrient, which could be considered an adaptive mechanism in response to high Mn levels. However this was not 
observed. A possible cause could be related to a reduction in the metabolic activity in the roots of the sensitive clone, as this tissue was the first to be negatively altered under hypoxia (Figure 2D). Besides, the intensity of the hypoxia applied may have been too severe.

\section{EXPERIMENT II}

HYPOXIA
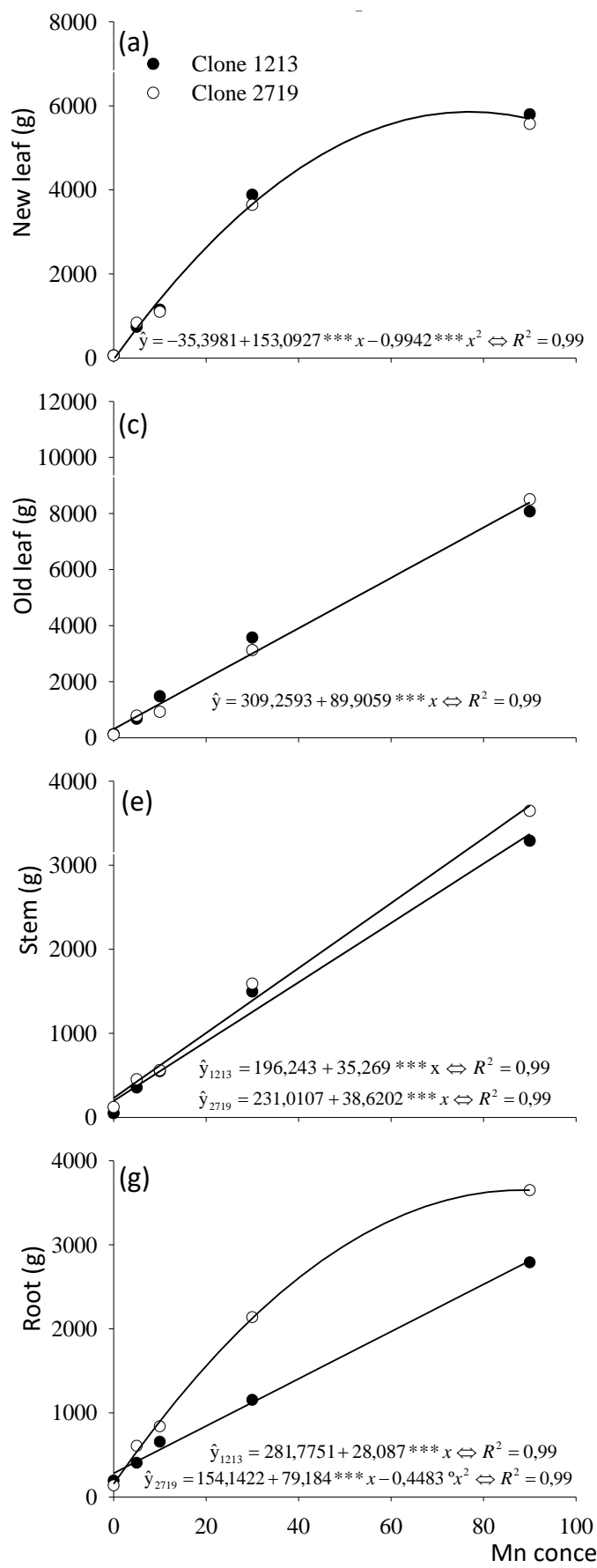

NORMAL

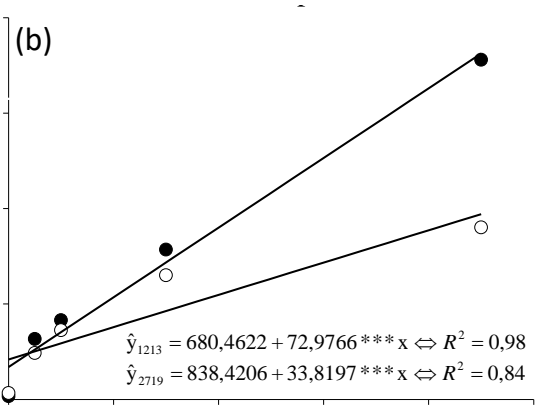

(d)

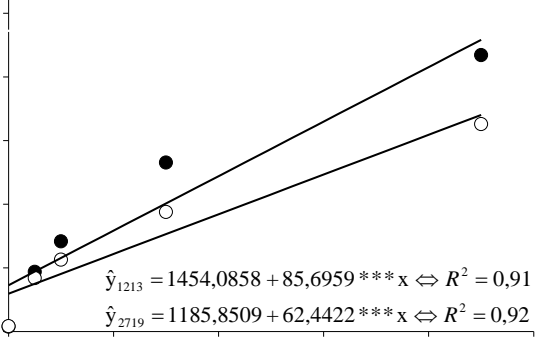

(f)

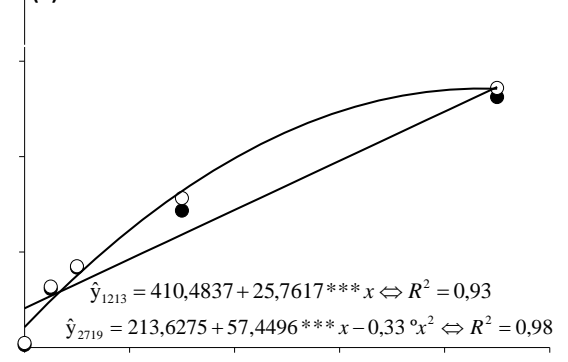

(h)

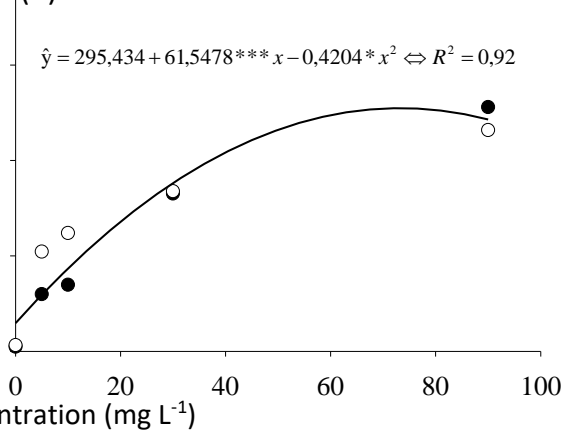

Figure 3. Mn contents in new leaves (a, b) and old (c, d), stem (e, f) and root (g, h) in eucalyptus seedlings (clones $1213 \circledR$ and $2719 \circledR$ CENIBRA SA) influenced by concentrations of Mn and O2, at 25 days. ${ }^{\circ}$; *; ***: significant at 10,5 and $0.1 \%$, respectively, by the $\mathrm{F}$ test. 


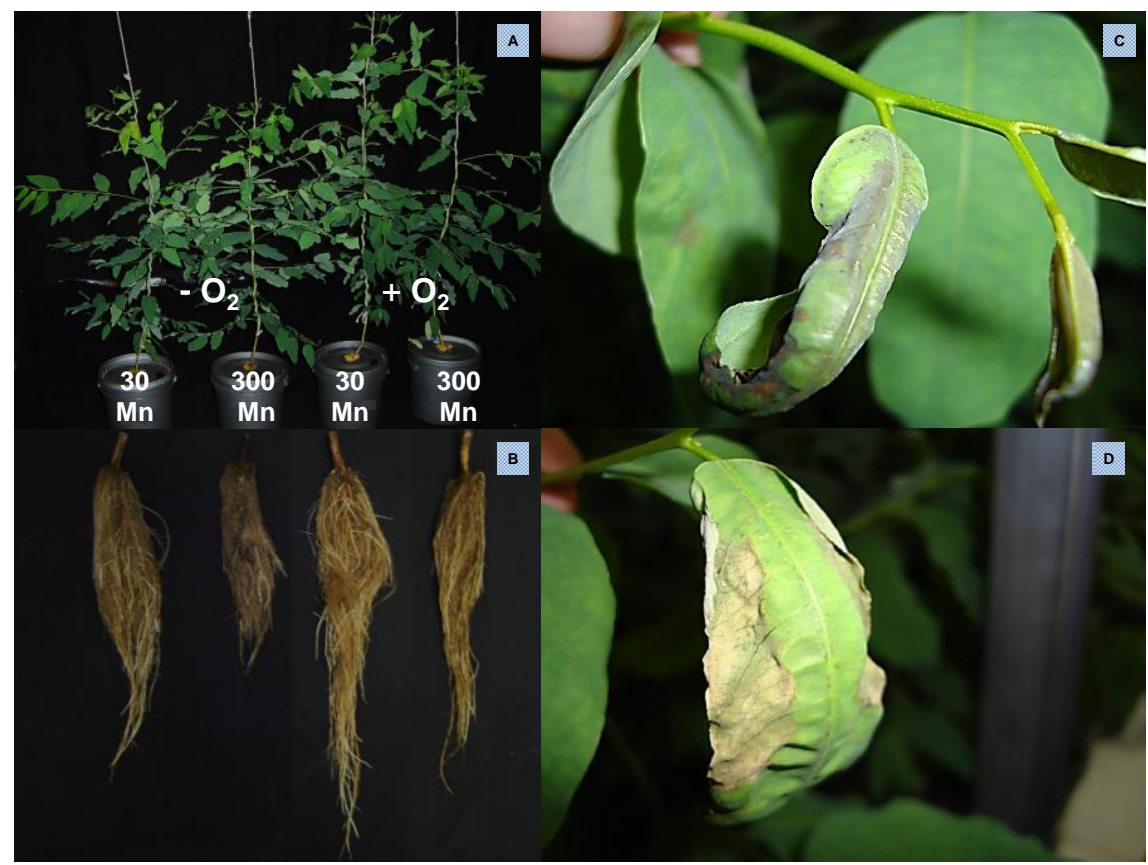

Figure 4. Growth of aerial part (A) and root system (B) of the sensitive clone (1213®) submitted to the normal condition (8 mg L-1 of O2) (+ O2) and hypoxia (6 mg L-1 of O2) (- O2), combined with two Mn concentrations

(30 and $300 \mathrm{mg} \mathrm{L-1)}$; Initial symptom of Mn toxicity in new leaf (C) and, in a more advanced phase (D), in clone $1213 \AA$ (6 mg L-1 of O2 and $300 \mathrm{mg} \mathrm{L}-1$ of Mn).

Table 1. Mean values of shoot height (MSH), shoot height (SH), ethylene concentration (EC), stem diameter (D) and root growth (RG) of eucalyptus seedlings 1213®-sensitive and 2719®-SPEVRD-tolerant), as a function of $\mathrm{Mn}$ and $\mathrm{O} 2$ concentrations

\begin{tabular}{|c|c|c|c|c|c|c|}
\hline $\mathrm{O}_{2}$ & Mn & MSH & SH & EC & D & RG \\
\hline \multirow{2}{*}{\multicolumn{2}{|c|}{$\mathrm{mg} \mathrm{L}^{-1}$}} & $\mathrm{~cm}$ & $\mathrm{~cm}$ & $\mu \mathrm{g} \mathrm{kg}^{-1}$ & $\mathrm{~mm}$ & $\mathrm{~cm}$ \\
\hline & & \multicolumn{5}{|c|}{ Clone 1213} \\
\hline 6 & 30 & $21,4 \mathrm{AbB}$ & $65,5 \mathrm{Ab} B$ & $144,4 \mathrm{Aa} A$ & $5,2 \mathrm{Aa} A$ & 7,7 $\mathrm{Ab} B$ \\
\hline 6 & 300 & $22,5 \mathrm{Ab} A$ & $69,0 \mathrm{Aa} A$ & $126,9 \mathrm{Aa} A$ & 4,9 Аa $A$ & 7,6 $\mathrm{Ab} B$ \\
\hline 8 & 30 & $26,1 \mathrm{Ab} A$ & $71,6 \mathrm{Ab} A$ & $94,9 \mathrm{Aa} B$ & $5,8 \mathrm{Aa} A$ & $13,3 \mathrm{Ab} A$ \\
\hline \multirow[t]{2}{*}{8} & 300 & $22,7 \mathrm{Bb} A$ & $63,2 \mathrm{Bb} B$ & $77,4 \mathrm{Ba} B$ & $5,2 \mathrm{Aa} A$ & $13,0 \mathrm{Aa} A$ \\
\hline & & \multicolumn{5}{|c|}{ Clone 2719} \\
\hline 6 & 30 & $32,5 \mathrm{Aa} A$ & $75,3 \mathrm{Aa} A$ & $110,8 \mathrm{Ab} A$ & $5,5 \mathrm{Aa} A$ & $16,1 \mathrm{Aa} A$ \\
\hline 6 & 300 & $32,1 \mathrm{Aa} A$ & $55,8 \mathrm{Bb} B$ & $111,7 \mathrm{Aa} A$ & 5,4 Aa $A$ & $12,2 \mathrm{Aa} A$ \\
\hline 8 & 30 & $35,4 \mathrm{Aa} A$ & $77,2 \mathrm{Aa} A$ & $77,6 \mathrm{Ab} B$ & $5,4 \mathrm{Aa} A$ & $19,5 \mathrm{Aa} A$ \\
\hline 8 & 300 & 30,0 Aa $A$ & $74,4 \mathrm{Aa} A$ & $58,8 \mathrm{Bb} B$ & $5,3 \mathrm{Aa} A$ & $14,1 \mathrm{Ba} A$ \\
\hline
\end{tabular}

Means followed by upper case vertical letters for the same clone and $\mathrm{O}_{2}$ do not differ in concentrations of Mn by the Tukey test at 5\%. Means followed by lower case vertical letters for the same $\mathrm{Mn}$ and $\mathrm{O}_{2}$ concentration do not differ for clones by the Tukey test at $5 \%$. Means followed by equal vertical and vertical capital letters for the same clone and concentration of $\mathrm{Mn}$ do not differ as to $\mathrm{O}_{2}$ concentrations by the $5 \%$ Tukey test. 


\section{Macrothink}

Table 2. Mean dry matter of root (R), stem (S), new leaf (NL), old leaf (OL), shoot (S) and total (T) seedling (1213®-sensitive clones and $2719 \AA$-resolerant to SPEVRD), as a function of $\mathrm{Mn}$ and $\mathrm{O}_{2}$ concentration

\begin{tabular}{|c|c|c|c|c|c|c|c|}
\hline $\mathrm{O}_{2}$ & Mn & $\mathbf{R}$ & $\mathbf{S}$ & NL & OL & $\mathbf{S}$ & $\mathbf{T}$ \\
\hline \multirow{2}{*}{\multicolumn{2}{|c|}{$\mathrm{mg} \mathrm{L}^{-1}$}} & \multicolumn{6}{|c|}{$\mathrm{g}_{\text {plant }}{ }^{-1}$} \\
\hline & & \multicolumn{6}{|c|}{ Clone 1213} \\
\hline 6 & 30 & $4,7 \mathrm{Ab} A$ & $6,6 \mathrm{Aa} B$ & $0,35 \mathrm{Ab} B$ & $5,3 \mathrm{Aa} B$ & $12,2 \mathrm{Aa} B$ & $17,0 \mathrm{Aa} B$ \\
\hline 6 & 300 & 4,6 Аa $A$ & $7,0 \mathrm{Aa} A$ & $0,31 \mathrm{Aa} A$ & $5,2 \mathrm{Aa} A$ & $12,5 \mathrm{Aa} A$ & 17,2 Аa $A$ \\
\hline 8 & 30 & 4,9 Аa $A$ & 9,1 $\mathrm{Aa} A$ & $0,48 \mathrm{Aa} A$ & $6,1 \mathrm{Aa} A$ & $15,7 \mathrm{Aa} A$ & $20,6 \mathrm{Aa} A$ \\
\hline \multirow[t]{2}{*}{8} & 300 & $4,6 \mathrm{Ab} A$ & $6,8 \mathrm{Bb} A$ & $0,31 \mathrm{Bb} A$ & $5,8 \mathrm{Aa} A$ & $12,9 \mathrm{Ba} A$ & $17,6 \mathrm{Bb} A$ \\
\hline & & \multicolumn{6}{|c|}{ Clone 2719} \\
\hline 6 & 30 & $5,4 \mathrm{Aa} A$ & 7,5 $\mathrm{Aa} B$ & $0,53 \mathrm{Aa} A$ & $5,0 \mathrm{Aa} A$ & $13,1 \mathrm{Aa} A$ & $18,5 \mathrm{Aa} A$ \\
\hline 6 & 300 & $4,7 \mathrm{Ba} B$ & $5,7 \mathrm{Bb} B$ & $0,36 \mathrm{Ba} B$ & $2,8 \mathrm{Bb} B$ & $8,9 \mathrm{Bb} B$ & $13,7 \mathrm{Bb} B$ \\
\hline 8 & 30 & $5,2 \mathrm{Aa} A$ & 8,9 Аa $A$ & $0,55 \mathrm{Aa} A$ & $5,4 \mathrm{Aa} A$ & $14,9 \mathrm{Aa} A$ & $20,2 \mathrm{Aa} A$ \\
\hline 8 & 300 & $5,5 \mathrm{Aa} A$ & $8,5 \mathrm{Aa} A$ & $0,55 \mathrm{Aa} A$ & $6,1 \mathrm{Aa} A$ & $12,2 \mathrm{Aa} A$ & $20,8 \mathrm{Aa} A$ \\
\hline
\end{tabular}

Means followed by upper case vertical letters for the same clone and $\mathrm{O}_{2}$ do not differ in concentrations of Mn by the Tukey test at 5\%. Means followed by lower case vertical letters for the same $\mathrm{Mn}$ and $\mathrm{O}_{2}$ concentration do not differ for clones by the Tukey test at 5\%. Means followed by equal vertical and vertical capital letters for the same clone and concentration of $\mathrm{Mn}$ do not differ as to $\mathrm{O}_{2}$ concentrations by the $5 \%$ Tukey test.

\subsection{Analyses of the Dry Matter from the Plant Components}

At the highest concentration of $\mathrm{Mn}\left(300 \mathrm{mg} \mathrm{L}^{-1}\right)$ under normal oxygenation $\left(8 \mathrm{mg} \mathrm{L}^{-1}\right)$ provoked reduced growth on the aerial part of the plant in the sensitive clone (Tables 1 and 2).

Under mild hypoxia $\left(6 \mathrm{mg} \mathrm{L}^{-1}\right)$, only the height of the tolerant clone was affected negatively by the highest concentration of $\mathrm{Mn}$, not causing reduced growth of roots, stem and stem diameter in both clones (Table 1). However, there was a lower production of dry matter for all the plant components at the highest dose of Mn under $6 \mathrm{mg} \mathrm{L}^{-1}$ of $\mathrm{O}_{2}$ for the tolerant clone (Table 2). The same effects were not observed for the sensitive clone. These observations suggest that excess Mn was more damaging to the growth of the sensitive clone under normal $\mathrm{O}_{2}$ conditions. On the other hand, under hypoxia the highest dose of $\mathrm{Mn}$ was the most limiting for the growth of the tolerant clone. This was confirmed by the data from the total production of dry matter of the plants, in which the sensitive clone produced the highest accumulation of biomass under hypoxia. In contrast, under normal $\mathrm{O}_{2}$ level and the highest dose of Mn, the tolerant clone performed the best (Table 2). 
Table 3. Mean levels of manganese in eucalyptus seedlings (clones $1213 ®$-sensitive and

2719®-SPEVRD-tolerant), as a function of Mn (treatment) and O2 concentration

\begin{tabular}{|c|c|c|c|c|c|}
\hline $\mathbf{O}_{2}$ & Treatment $^{(1)}$ & Mn & $\mathbf{O}_{2}$ & Treatment $^{(1)}$ & Mn \\
\hline & $\mathrm{mg} \mathrm{L}^{-1}$ & $\mathrm{mg} \mathrm{kg}^{-1}$ & & $m g L^{-1}$ & $\mathrm{mg} \mathrm{kg}^{-1}$ \\
\hline & Root & & & New leaf & \\
\hline \multicolumn{6}{|c|}{ Clone 1213} \\
\hline 6 & 30 & $4704 \mathrm{Bb} A$ & 6 & 30 & $7267 \mathrm{Ba} A$ \\
\hline 6 & 300 & $17298 \mathrm{Aa} A$ & 6 & 300 & $19152 \mathrm{Aa} A$ \\
\hline 8 & 30 & $4788 \mathrm{Bb} A$ & 8 & 30 & $9647 \mathrm{Ba} A$ \\
\hline 8 & 300 & $16625 \mathrm{Aa} A$ & 8 & 300 & $12461 \mathrm{Aa} B$ \\
\hline \multicolumn{6}{|c|}{ Clone 2719} \\
\hline 6 & 30 & $6524 \mathrm{Ba} A$ & 6 & 30 & $4560 \mathrm{Bb} B$ \\
\hline 6 & 300 & $15310 \mathrm{Aa} B$ & 6 & 300 & $8983 \mathrm{Ab} A$ \\
\hline 8 & 30 & $6134 \mathrm{Ba} A$ & 8 & 30 & $6061 \mathrm{Bb} A$ \\
\hline 8 & 300 & $19006 \mathrm{Aa} A$ & 8 & 300 & $9326 \mathrm{Ab} A$ \\
\hline & Stem & & & Old leaf & \\
\hline \multicolumn{6}{|c|}{ Clone 1213} \\
\hline 6 & 30 & $2779 \mathrm{Bb} B$ & 6 & 30 & $5412 \mathrm{Ba} A$ \\
\hline 6 & 300 & $5471 \mathrm{Aa} A$ & 6 & 300 & $11030 \mathrm{Aa} A$ \\
\hline 8 & 30 & $3326 \mathrm{Ba} A$ & 8 & 30 & $5921 \mathrm{Ba} A$ \\
\hline 8 & 300 & $5398 \mathrm{Ab} A$ & 8 & 300 & $9484 \mathrm{Aa} A$ \\
\hline \multicolumn{6}{|c|}{ Clone 2719} \\
\hline 6 & 30 & $3004 \mathrm{Ba} B$ & 6 & 30 & $4235 \mathrm{Ba} B$ \\
\hline 6 & 300 & $5294 \mathrm{Aa} A$ & 6 & 300 & $7173 \mathrm{Ab} B$ \\
\hline 8 & 30 & $3664 \mathrm{Ba} A$ & 8 & 30 & $5856 \mathrm{Ba} A$ \\
\hline 8 & 300 & $5868 \mathrm{Aa} A$ & 8 & 300 & $10123 \mathrm{Aa} A$ \\
\hline
\end{tabular}

(1)Treatment: Mn concentration added for each treatment; means followed by upper case vertical letters for the same clone and $\mathrm{O} 2$ do not differ in Mn concentrations by Tukey test at 5\%. Means followed by lower case vertical letters for the same concentration of $\mathrm{Mn}$ in the treatment and $\mathrm{O} 2$ did not differ for clones by Tukey test at $5 \%$. Means followed by equal vertical and vertical capital letters for the same clone and concentration of Mn do not differ as to $\mathrm{O} 2$ concentrations by the $5 \%$ Tukey test.

\section{Root growth}

Excess Mn had no effect on root growth in both the clones, except of the tolerant clone under normal $\mathrm{O}_{2}$ (Table 1). The root growth of the sensitive clone was extremely sensitive to hypoxia, presenting a $41 \%$ reduction in growth, independent of the Mn concentration. Thus hypoxia is extremely damaging to the growth of the root system, as observed by other authors (George et al., 2012; Júnior et al., 2015; Muhammad et al., 2016; Shao et al., 2016; Xue et al., 2015). The same effect was not observed in the tolerant clone, supporting the idea that its root system is superior under mild hypoxia. Additionally, the reduced root growth could be attributed to the elevated concentration of ethylene (Muhammad et al., 2016). In flooded soils, 
the ethylene produced by the roots stimulates the biosynthesis of auxin (Lynch et al., 2012), when transported to the zone of root growth could inhibit cellular elongation, reducing root growth (Shimamura et al., 2016).

Throughout the experimental period (27 days), the daily root growth was reduced in both clones in response to $\mathrm{O}_{2}$ and $\mathrm{Mn}$ concentrations (Figure 4). Again, the effect of hypoxia was much more pronounced than that of the high concentration of $\mathrm{Mn}$. Under hypoxia, independent of the concentration of $\mathrm{Mn}$ or the clone used, the daily root growth was always lower than that under normal oxygenation.

\section{Synthesis of ethylene}

Anaerobic stress triggered significant ethylene production in both clones (Table 1), with the sensitive one showing a larger increase. However, Mn did not influence this increase under hypoxia. Similar results occurred in E. camaldulensis, E. globulus, E. obliqua (Blake and Reid, 1981) and E. robusta (Clemens and Pearson, 1977) under flooding, suggesting that the production of this hormone is one of the principal physiological modifications that occur under hypoxia in eucalyptus. Under hypoxic conditions expression of the gens that regulate the production of ethylene is intensified (Alpuerto et al., 2016; Dong et al., 2016), altering the growth and morphology of the root system. This higher production of ethylene corroborates the results presented in experiments I and II, since reduction in the growth of the root system (Phukan et al., 2015) and the formation of aerenchyma (Drew et al., 1989; He et al. 1996, Shimamura et al., 2016), are closely correlated with the production of this hormone in hypoxic conditions.

\section{Mn toxicity}

The increase in the concentration of $\mathrm{Mn}$ from 30 to $300 \mathrm{mg} \mathrm{L}^{-1}$, under hypoxia or not, elevated the level of this micronutrient in all the plant compartments in both clones (Table 3 ). The sensitive clone accumulated more and in general the higher levels were observe in the leaves. This result together with those observed in the field, where the clones are more sensitive to ESBVRD, presented higher levels of Mn in the leaves (Leite et al., 2014). In this study, the levels of Mn in the sensitive clone reached 11000 and $19000 \mathrm{mg} \mathrm{kg}^{-1}$ in mature and young leaves, respectively. For the tolerant clone, close to 6000 and $9000 \mathrm{mg} \mathrm{kg}^{-1}$ were observed in mature and young leaves, respectively. However, this did not result in higher levels of $\mathrm{Mn}$ in the root system of the sensitive clone, indicating that the higher tolerance of the tolerant clone to Mn excess, although the levels of $\mathrm{Mn}$ in the roots were similar to those found in the roots of the sensitive clone, could be linked to a limitation in the rate of absorption or translocation to the aerial part of the plant.

Under hypoxia and Mn excess, the sensitive clone showed loss of apical dominance and a brownish necrosis in young leaves, and with time they became wrinkled and necrotic (Figures 4C and D). The level of leaf $\mathrm{Mn}$ in this condition was $19000 \mathrm{mg} \mathrm{kg}^{-1}$, suggesting that this level is toxic for the sensitive clone (Table 3). Similar symptoms have been observed in eucalyptus by Winterhalder (1963); however, in this study, besides these symptoms, the leaves were small and chlorotic. This can be attributed to the limitation that the excess of $\mathrm{Mn}$ 
causes on the absorption of Fe (Eroglu et al., 2015). In the same study by Winterhalder (1963), E. gummifera was the most sensitive to $\mathrm{Mn}$ in the soil, while E. saligna was able to absorb large quantities of this micronutrient without showing symptoms of toxicity. The levels of Mn observed in the leaves of E. gummifera and E. saligna were 2040 and $4250 \mathrm{mg}$ $\mathrm{kg}^{-1}$, respectively, with an adequate level of Mn being $510 \mathrm{mg} \mathrm{kg}^{-1}$. These observations suggest that there are different levels of tolerance to Mn among the species of eucalyptus, as reported by El-Jaoual and Cox (1998), with E. urograndis being generally classified as one of the more tolerant species to an excess Mn.

Among the symptoms characteristic of Mn toxicity are brownish lesions, loss of apical dominance, leaf wrinkling (Asati et al., 2016), cracks in the lateral branches also occur with high frequency in ESBVRD. As previously described, some of these symptoms resemble those presented in the field, such as brownish lesions and leaf wrinkling. However, lesions in stems/stalks, petioles and branches were not observed under greenhouse conditions. Such information indicates that the time of exposure to Mn could have been too short for the full expression of these symptoms. However, indicating Mn as the cause of the ESBVRD is still not reliable, mainly because the plants that are exposed to excess Mn are subject to several other complications arising from the hypoxic condition.

\section{Conclusions}

Pronounced hypoxia causes reduced growth of both clones, sensitive and ESBVRD-tolerant, although the effect is more accentuated in the sensitive clone, being root growth the best indicator of the stress caused by hypoxia; Mn did not influence this evaluation. Mild hypoxia triggered the greatest increase in ethylene production in the sensitive clone and $\mathrm{Mn}$ did not influence this increase as well. Nevertheless, the visual symptoms of Mn toxicity occurred only in young leaves of the sensitive clone, characterized by the formation of brownish necrosis on the leaf edges, followed by wrinkling, with hypoxia being the first factor that predisposes the clones to ESBVRD which Mn excess acts in the long term for the complete expression of the characteristic symptoms.

\section{Acknowledgements}

We would like to thank the Soil Science Department and the Plant Biology Department at Viçosa Federal University, for the help and support on the project. Also, the Celulose Nipo Brasileira S/A for its assistant on this research. Our acknowledgments for the founding sources CAPES (Coordination of Improvement of Higher Level Personnel) and CNPQ (National Counsel of Technological and Scientific Development).

\section{References}

Alpuerto, J. B., Hussain, R. M. F., \& Fukao, T. (2016). The key regulator of submergence tolerance, SUB1A, promotes photosynthetic and metabolic recovery from submergence damage in rice leaves. Plant, Cell and Environment 39: 672-684. doi:10.1111/pce.12661

Andrade, W. V., Santos Filho, B. G., Lobato, A. K. S., Tan, D. K. Y., Oliveira Neto, C. F., Pereira, A. C. C, \& Okumura, R. S. (2015). Negative interference on growth and 
morpho-anatomical modifications in young Parkia gigantocarpa plants under waterlogging. Australian Journal of Crop Science 9(6): 523.

Asati, A., Pichhode, M., \& Nikhil, K. (2016). Effect of Heavy Metals on Plants: An Overview 5:56-66.

Bailey-Serres, J., \& Voesenek, L. A. C. J. (2008). Flooding Stress: Acclimations and Genetic Diversity. Annual Review of Plant Biology 59: 313-39.

doi:10.1146/annurev.arplant.59.032607.092752

Blake, T. J., \& Reid, D. M. (1981). Ethylene, Water Relations and Tolerance to Waterlogging of Three Eucalyptus Species. Australian Journal of Plant Physiology 8: 497-505.

doi:10.1071/PP9810497

Broadley, M., Brown, P., Cakmak, I., Rengel, Z., \& Zhao, F. (2012). Function of Nutrients: Micronutrients In Marschner's Mineral Nutrition of Higher Plants, ed. Marschner, P. 191-248. New York, Academic Press.

Clemens, J., \& Pearson, C. J. (1977). The effect of waterlogging on the growth and ethylene content of Eucalyptus robusta Sm. (Swamp Mahogany). Oecologia 29: 249-255.

doi:10.1007/BF00345699

Dong, Z., Yu, Y., Li, S., Wang, J., Tang, S., \& Huang, R. (2016). Abscisic Acid Antagonizes Ethylene Production through the ABI4-Mediated Transcriptional Repression of ACS4 and ACS8 in Arabidopsis. Molecular Plant 9: 126-135. doi:10.1016/j.molp.2015.09.007

Drew, M. C., He, C. J., \& Morgan, P. W. (1989). Decreased ethylene biosynthesis, and induction of aerenchyma, by nitrogen- or phosphate-starvation in adventitious roots of Zea mays L. Plant Physiology 91: 266-71.

El-Jaoual, T., \& Cox, D. A. (1998). Manganese toxicity in plants. Journal of Plant Nutrition 21: 353 - 386. doi:10.1080/01904169809365409

Eroglu, S., Meier, B., von Wirén, N., \& Peiter, E. (2015). The vacuolar manganese transporter MTP8 determines tolerance to Fe deficiency-induced chlorosis in Arabidopsis. Plant physiology 170: 1030-1045. doi:10.1104/pp.15.01194

George, E., Horst, W. J., \& Neumann, E. (2012). Adaptation of Plants to Adverse Chemical Soil Conditions In Marschner's Mineral Nutrition of Higher Plants, ed. Marschner, P. 409-72. New York, Academic Press.

Gonçalves, J. L. M., Raij, B., \& Gonçalves, J. C. (1996). Florestais In Recomendações de adubação e calagem para o Estado de São Paulo, eds. Raij, B., Cantarella, H., Quaggio, J.A., Furlani, A.M.C., 245-59, Campinas: Instituto Agronômico e Fundação IAC.

He, C. J., Morgan, P. W., \& Drew, M. C. (1996). Transduction of an ethylene signal required for cell death and lysis in the root cortex of maize during aerenchyma formation during hypoxia. Plant Physiology 112:463-72.

Huang, X., Shabala, S., Shabala, L., Rengel, Z., Wu, X., Zhang, G., Zhou, M. (2015). Linking 
waterlogging tolerance with Mn2+ toxicity: A case study for barley. Plant Biology 17: 26-33. doi:10.1111/plb.12188

Júnior, W. V. A., Filho, B. G. S., Lobato, A. K. da S., Tan, D. K. Y., Neto, C. F. de O., Pereira, A. C. da C., da Cunha, R. L. M., da Costa, R. C. L., Kikuchi, T. Y. S., \& Okumura, R. S. (2015). Negative interference on growth and morpho-anatomical modifications in young Parkia gigantocarpa plants under waterlogging. Australian Journal of Crop Science 9: 523-531.

Keunen, E., Schellingen, K., Vangronsveld, J., \& Cuypers, A. (2016). Ethylene and Metal Stress: Small Molecule, Big Impact. Frontiers in plant science 7: 23. doi:10.3389/fpls.2016.00023

Khabaz-Saberi, H., Setter, T. L., \& Waters, I. (2006). Waterlogging Induces High to Toxic Concentrations of Iron, Aluminum, and Manganese in Wheat Varieties on Acidic Soil. Journal of Plant Nutrition 29: 899-911. doi:10.1080/01904160600649161

Leite, F. P., Novais, R. F., Silva, I. R., Félix, N., César, J., Neves, L., Medeiros, A. G. B., \& Contin, M. (2014). Revista Brasileira de Ciência do Solo 38:193-204.

doi:10.1590/S0100-06832014000100019

Lidon, F. C., \& Teixeira, M. G. (2000). Rice tolerance to excess Mn: Implications in the chloroplast lamellae and synthesis of a novel Mn protein. Plant Physiology and Biochemistry 38: 969-978. doi:10.1016/S0981-9428(00)01207-9

Lynch, J., Marschner, P., \& Rengel, Z. (2012). Effect of internal and external factors on root growth and development In Marschner's Mineral Nutrition of Higher Plants, ed. Marschner, P. 331-346. New York, Academic Press.

Malavolta, E., Vitii, G. C., \& Oliveira, S. A. (1989). Avaliação do estado nutricional das plantas: princípios e aplicações. Piracicaba, Potafos.

Muhammad, N., Cai, S., Shah, J. M., \& Zhang, G. (2016). The combined treatment of Mn and $\mathrm{Al}$ alleviates the toxicity of $\mathrm{Al}$ or Mn stress alone in barley. Acta Physiologiae Plantarum 38. doi:10.1007/s11738-016-2296-2

Nascimento, W. M. O., Cruz, E. D., Moraes, M. H. D., \& Menten, J. O. M. (2006). Qualidade sanitária e germinação de sementes de Pterogyne nitens Tull. (Leguminosae Caesalpinioideae). Revista Brasileira de Sementes 28: 149-153.

Novais, R. F., Barros, N. F., \& Neves, J. C. L. (1990). Nutrição Mineral do eucalipto In Relação solo-eucalipto, eds. Barros, N.F. and Novais, R.F. Viçosa, MG, Editora Folha de Viçosa.

Peng, H. P., Lin, T. Y., Wang, N. N., \& Shih, M. C. (2005). Differential expression of genes encoding 1-aminocyclopropane-1-carboxylate synthase in Arabidopsis during hypoxia. Plant Molecular Biology 58: 15-25. doi:10.1007/s11103-005-3573-4

Phukan, U. J., Mishra, S., \& Shukla, R. K. (2016). Waterlogging and submergence stress: 
affects and acclimation. Critical reviews in biotechnology 36(5): 956-966.

Shao, J. F., Yamaji, N., Shen, R. F., \& Ma, J. F. (2016). The Key to Mn Homeostasis in Plants: Regulation of Mn Transporters. Trends in Plant Science 1-10.

doi:10.1016/j.tplants.2016.12.005

Shimamura, S., Nishimura, T., Koshiba, T., Yamamoto, R., Hiraga, S., Nakamura, T., \& Komatsu, S. (2016). Effects of anti-auxins on secondary aerenchyma formation in flooded soybean hypocotyls. Plant Production Science 19: 154-160.

doi:10.1080/1343943X.2015.1128101

Silva, I. R., Novais, R. F., Jham, G. N., Barros, N. F., Gebrim, F. O., Nunes, F. N., Neves, J. C. L., \& Leite, F. P. (2004). Responses of eucalypt species to aluminum: the possible involvement of low molecular weight organic acids in the Al tolerance mechanism. Tree physiology 24: 1267-1277. doi:10.1093/treephys/24.11.1267

Taiz, L., \& Zeiger, E. (2006). Fisiologia vegetal. Porto Alegre, Artmed.

Telewski, F. W. (2016). Flexure wood: mechanical stress induced secondary xylem formation In Secondary Xylem Biology: Origins, Functions, and Applications, 73.

Urano, K., Maruyama, K., Jikumaru, Y., Kamiya, Y., Yamaguchi - Shinozaki, K., \& Shinozaki, K. (2017). Analysis of plant hormone profiles in response to moderate dehydration stress. The Plant Journal 90: 17-36. doi: 10.1111/tpj.13460

Wang, X., Huang, M., Zhou, Q., Cai, J., Dai, T., Cao, W., \& Jiang, D. (2016). Physiological and proteomic mechanisms of waterlogging priming improves tolerance to waterlogging stress in wheat (Triticum aestivum L.). Environmental and Experimental Botany 132: 175-182. doi:10.1016/j.envexpbot.2016.09.003

Winterhalder, E. K. (1963). Differential resistance of two species of Eucalyptus to toxic soil manganese levels. Austalian Journal of Soil Science 25: 363-4.

Wu, S. (1994). Effect of manganese excess on the soybean plant cultivated under various growth conditions. Journal of Plant Nutrition 17: 993-1003.

Xue, S., Zhu, F., Wu, C., Lei, J., Hartley, W., \& Pan, W. (2015). Effects of manganese on the microstructures of Chenopodium ambrosioides L., a manganese tolerant plant. International journal of phytoremediation 18: 710-719. doi:10.1080/15226514.2015.1131233

Zhang, M., Smith, J. A. C., Harberd, N. P., \& Jiang, C. (2016). The regulatory roles of ethylene and reactive oxygen species (ROS) in plant salt stress responses. Plant Molecular Biology 91: 651-659. doi:10.1007/s11103-016-0488-1 


\section{Macrothink}

Journal of Agricultural Studies

ISSN 2166-0379

\section{Copyright Disclaimer}

Copyright for this article is retained by the author(s), with first publication rights granted to the journal.

This is an open-access article distributed under the terms and conditions of the Creative Commons Attribution license (http://creativecommons.org/licenses/by/4.0/). 